\title{
INDIA'S ROLE AS A REGIONAL POWER: IMPLICATIONS FOR PAKISTAN-CHINA ALLIANCE
}

\author{
Majid Ali Noonari* \\ Dr Muhammad Ali Pasha ${ }^{+}$ \\ Imran Ali Noonari
}

\begin{abstract}
India is one of the emerging states of the Asia pacific region and its emergence as an economic and political power house in the region has made it an important player in regional politics. Since the turn of the century the US tilt towards New Delhi has further highlighted its importance in the region. Look East Policy of India is designed to increase the New Delhi's role as the regional power in the East Asian affairs and counter the Beijing's influence in the region and in rise as a competitor to the US role as superpower. US Asia Pivot strategy aimed to contain the power and influence of the Beijing, has presented New Delhi as a natural ally of Washington in the region. New Delhi's continued hostility towards Islamabad has projected the Indian rise a threat to the strategic partnership of Pakistan and China. Washington's support for enhanced role of New Delhi in global affairs and its proposal to include a permanent member of UN and other prestigious global organization can be viewed as a support to India to advance its interests in the region. The researchers have analysed the role and policies adopted by the New Delhi and its increasing nexus with Washington in order to understand the rise of India as a regional power and its impact over the PakChina nexus in the changing global scenario.
\end{abstract}

Key Words: Linchpin, Asia Pivot, Nexus, Containment

\footnotetext{
* Lecturer, Area Study Centre, Far East \& Southeast Asia, University of Sindh, Jamshoro, Pakistan. Email: majid.noonari@usindh.edu.pk (Corresponding Author) + Assistant Professor, Department of Economics, University of Sindh, Jamshoro, Pakistan. Email: m.pasha@usindh.edu.pk

$\ddagger$ Assistant Professor, Department of Political Science, University of Sindh, Jamshoro, Pakistan. Email: imran.noonari@usindh.edu.pk
} 


\section{Introduction}

India has emerged as one of the new economic powerhouses, and its partnership with US has further strengthened its image as a leading regional power, and seen as a counterbalance to the Peoples Republic of China (PRC). India is a state with over one billion population and huge natural resources can challenge the China as it remains the main competitor in South Asian region. China is the largest trading partner of India with over $\$ 70$ billion trade despite being the major competitor. Indian Prime Minister Narendra Modi has reversed the Indian decision to join the Regional Comprehensive Economic Partnerships (RECP) which it had earlier signed in 2012 in order to block the Chinese goods flood in Indian markets (Mourdoukoutas, 2019). New Delhi also sent its forces in Doklam in 2016 on the request of Bhutan's government in order to protect it from Chinese construction of road. The rise of India in the region has been worrisome for the China and Pakistan as it will increase the hostility in the region.

\section{Historical Background}

India during the cold war years has tried to establish its role as a regional power but during these years the world was divided in two blocs communist and capitalists, which have reduced the emergence of the regional powers. But New Delhi tried to maintain her sovereignty by not joining any bloc during the cold war years in order to achieve her national interests (Kissinger, p-204). New Delhi was one of the founding members of the Non-Aligned Movement (NAM) in 1961. New Delhi has maintained its neutrality in regional affairs during the Korean war of 1950-53 when she warned Washington of Beijing's ambition to join the Pyongyang's side in the war. Although New Delhi did not join the war but she tried to break a peace deal between Washington and Beijing (Riedel, 2017) and conveyed its message to Washington that Beijing will press the Pyongyang if its seat at the United Nations Security Council (UNSC) was restored. 
New Delhi jeopardized its relations with the Beijing in the late 1950s by exercising its influence in the region when in 1959 it welcomed the exiled Tibetan spiritual leader Dalai Lama, and provided support to the Lhasa rebellion in Tibet in March 1959.

The rise of Indian role as a regional power was halted by China in the region when the two superpowers were locked at the Cuban Missile Crisis $\$$ when the war broke out between the two nations in which India was outsmarted by the Beijing. New Delhi's defeat in 1962 conflict has ended its dream to dominate the region.

India has remained hostile towards Beijing since the 1962 war $^{* *}$ as the world (Lidarev, 2012) was focused towards the Cuban missile crisis, and China considered an opportunity to deal with Indian threat in Tibet. $^{+t}$ On the other hand, India continued to maintain hostile relations with its eastern neighbour Pakistan since their independence in 1947 over the disputed territory of Jammu and Kashmir. Malik (2019) argued that the relations began on a bitter note due to the killing of millions of people of different religions on both the sides, which resulted the beginning of new hostility. Pakistan and India fought wars in 1948, 1965, 1970-71, and 1999 and there were also

$\S$ Cuban Missile Crisis was a conflict between two superpowers, which happened between 16-28 October 1962 over the installation of Soviet nuclear missiles on Cuban soil. US put the blockade of Cuba until $21^{\text {st }}$ November 1962 the removal of last of the missiles from Cuba. The world during the crisis saw this crisis as a boiling point between the two superpowers.

** The war between the China and India began on 20 $0^{\text {th }}$ October 1962 when they were taken by surprise from Chinese armed forces as they did not believed in the Chinese attack so they remained ill prepared (India Today, 2016). The war came to an end on $21^{\text {st }}$ November in a Chinese victory.

${ }^{++}$Indian role in Tibet was considered a major threat to the Chinese rule in Tibet even though New Delhi acknowledged Chinese rule in Tibet in the 1954 Five principles of Peaceful Co-existence. Yet in 1959 welcomed the Dalai Lama in India which angered China, and Indian support to the Lhasa rebellion in Tibet in 1959 added the fuel to the fire as China perceived New Delhi a threat to its rule in Tibet. 
the standoff in 2001-02 $\ddagger$, and the so-called surgical strikes§§ which resulted in the Pakistani targeting of Mig-21 fighters of India in 2018.

New Delhi's involvement in the internal affairs of the states of the region shows her interest to acquire the regional power role since the independence in 1947. The takeover of the Kashmir through armed forces in 1947 has begun the conflict between two states over the disputed territory. But that did not end there rather India continued to influence the East Pakistan in order to create chaos in the newly founded state. New Delhi has tied with the Dhaka since their separation from Pakistan in 1971 and has played a significant role in their independence. New Delhi's friendly ties with the Bangladesh has created anti-Pakistan sentiments within Bangladeshi government.

The disintegration of Pakistan in two states has not weakened it as India tried to hold its influence in the region. According to Gupta (1975) Z.A. Bhutto played a significant role in bringing the regions of South East Asia, Middle East and China together to end New Delhi's

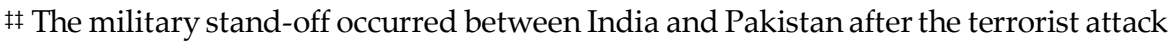
on Indian parliament on $13^{\text {th }}$ December 2001. The terrorist attack was blamed by India on Pakistani militant groups Lashkar-e-Taiba and Jaish-e-Mohammad and it held responsible to Pakistan. This led to the mobilization of Indian forces on the eastern border of Pakistan which lasted until $10^{\text {th }}$ June 2002. The de-escalation of the standoff begun after the international interference from different states.

$\S \S$ The Uri attack on Indian forces on $18^{\text {th }}$ September 2016 begun the fresh border skirmishes and India even claimed to have launched aerial strikes of Azad Kashmir which Pakistan denied and claimed that no such attack took place. The other border skirmishes begun in February 2019 when a suicide bomber killed 40 Indian soldiers and Indian air force violated the airspace of Pakistan on $26^{\text {th }}$ February and went to the Balakot where India dropped their payload and targeted few trees. This claim of Pakistani forces has been internationally recognized whereas India claimed that it has destroyed a terrorist camp which did not have any solid evidences. Pakistan in response to the Indian air violation launched a counter strike on 27th February 2019 in which an Indian MiG-21 jet was shot and its pilot Abhinandan Varthaman was arrested. The pilot was later released on $1^{\text {st }}$ March 2019, and two states agreed on peace offer on 22nd March 2019. 
efforts to isolate the Islamabad. Pakistan during the 1970s faced the US sanctions as a result Pakistan left the US backed alliances of South East Asian Treaty Organization (SEATO) and Central Treaty Organization (CENTO). The sanctions were lifted in 1975, but pressure mounted in 1976 when Ford administration warned Pakistan of obtaining nuclear processing plant from France. Pakistan ignored the signals from Washington and continued its nuclear programme in order to maintain the balance of power in the region, which has been disturbed due to Indian nuclear test in 1974.

Pakistan since 1960s, tilted towards Beijing and settled the border dispute in 1963. In 1966 started the military cooperation and in 1976 nuclear deal was signed with China. Pakistan's close affiliation with the Beijing has created a hurdle in New Delhi's approach to deal with Pakistan as she wanted to isolate Pakistan from western bloc, and has developed strategic partnership with Soviet Union in 1972. The 1970s was the turning point which almost ended the hopes of India to dominate the entire region as Sino-US relations took a new turn and Pakistan developed a strategic partnership with China in 1972. Despite US sanctions Pakistan has developed an important Islamic bloc and created a bridge for China to build relations with the Islamic states. The 1979 year has completely altered the balance in Pakistan's favour due to the Islamic Revolution in Iran in which the pro-west Shah of Iran was overthrown and anti-American regime came in power in the country. The other development was the Soviet's occupation of Afghanistan which has direct consequences for Pakistan and the west. US not only ended the sanctions in the 1980s but also provided military and economic assistance to the Pakistan. US in the 1980s provided the F-16 fighter jets to Pakistan in order to combat the Soviet aggression in the region and ensure its sovereignty from the external threats.

Washington changed its policy in the 1990s after the Soviet forces withdrawal from Afghanistan, and her policy towards the India became the central focus of the Washington's foreign policy but that 
could not be materialized until the turn of the century due to the Indian nuclear tests which compelled US to impose sanctions which were lifted in 2002. The Indo US Nuclear Deal has brought both the states closer towards each other and the 2011 US Asia Pivot Strategy has identified the New Delhi as a key partner in the containment of the China.

As Basit (2019) remarked that Washington's role in Islamabad has greatly reduced since 2011 due to the increased Chinese role in the region particularly the CPEC. On the other hand, Washington interest with New Delhi has increased since the turn of the century. Indo-US nexus has been not new as the policy makers in Washington has remained aspirant to include New Delhi in their plans for the region's security structure, but due to its role as a leader in the Non-Aligned Movement, and their partnership with the Soviet Union during the Cold War years they (U.S.) could not include New Delhi in their policies. But with the breakup of the Soviet Union and the end of the Cold war has refocused the policy makers in Washington on the New Delhi's importance as a natural ally in the region. The relations became closer during the 1990s and early 2000s, which culminated in the Indo-US nexus.

The growing trade war between US and China started the new conflict between two power centres and the tensions were further heightened during the latest outbreak of corona virus when both the states alleged each other for the horrors that has devastated the global losses to humans' economy. New Delhi's rise as a regional power presents an option for the Washington to empower it with the military and economic aid in order to create a competitor for the China in the region.

\section{Implications for Pak-China Alliance}

The rise of India as a regional power have certain implications for the Pakistan-China axis. Some of these are observed as under. 
1. India will play a significant role in isolating Pakistan in the region and has tried to establish cordial ties with the states of the region. Narendra Modi's policy of Minus Pakistan in the South Asian Association for Regional Cooperation (SAARC), and its policy to engage the Middle Eastern states, which are known as traditional partners of Islamabad. On the other hand, its policy of Act East which evolved from the early 1990s has been aimed to create partnership with the South East Asian states and contain the growing influence of the China in the region. India has been trying to create panic in the Pakistan by propagating against Pakistan in the name of terrorism and has blamed of the terrorist activities. Not only that but India has also used her influence in the region to isolate Islamabad with the help of the pro India governments such as Bangladesh and Afghan government on different issues. New Delhi has tried to reduce the role of Islamabad in SAARC by establishing the cooperation with other SAARC states on various issues, which will end (minus) the role of Pakistan.

2. Indian rise as a regional power has been exercised by terminating the Article 370 of the Indian Constitution on status of Jammu and Kashmir (Mourdoukoutas, 2019). Pakistan has raised the voice against the Indian efforts for brining demographic change in Kashmir by ending the status of Jammu and Kashmir, and the lockdown in Kashmir since August 5, 2019. New Delhi's oppressive policies against the minorities has been ignored by its strategic allies like US and western states but the more surprising is the response from Islamabad's traditional partners of Middle Eastern states. Pakistan on the issue was supported vocally by Malaysia, China and Turkey which shows the Indian role has become vital in the region.

New Delhi has emerged as a dominant player in the regional politics and has been able to influence its role in the region by putting 
pressure on the Sri Lankan government to cancel the JF-17 purchase from Pakistan and also has exerted influence in Sri Lankan elections in the past shows how powerful its influence has been on its neighbours (Hali, 2019).

Not only that but the influence it has exercised over the Bangladesh and Afghan government has been enormous and they have been antiPakistan over the years in order to appease the Indian government.

3. Indo-US relations over the years have strengthened and developed into a strategic alliance. The US has cooperated with India on many fronts and have influenced the Indian policy makers to forge a policy which will make it a front line state in the Asia Pacific region, and become a great challenger to the Chinese influence.

New Delhi's nexus with the Washington has been the major source of concern for the Pak-China alliance as it has main focus on the containment of China. Washington has been a prime driver against the containment of China in the region and has viewed it as a threat to its global role as superpower. The growing partnership with the Washington has its roots in the 1962 conflict when Washington provided the military and economic support to New Delhi and Pakistani president Ayub Khan viewed it as a threat to its security. He raised his concerns to the Washington but they unheard due to their own policy of containment against the communism and the other major cause was the US president John F. Kennedy's support towards New Delhi as he saw India as a natural partner/ally of the US.

Washington's role with Islamabad and New Delhi has varied over the years but at the end of the cold war era they became close partners and has played a significant role in reducing/eliminating the tensions in 1999 Kargil war, 2001-02 border conflict and 2008 tensions. IndoUS nexus has been the major concern for the Pak-China alliance as it is mainly aimed to reduce the Chinese role in the region by 
propagating against its development projects named BRI and CPEC ${ }^{* * *}$. They also have forged close cooperation in the region to contain the Chinese influence through multilateral partnerships and regional economic cooperation like Trans-Pacific Partnership (TPP) $)^{+++}$. New Delhi has signed the Indo-US Nuclear Deal in 2006, and has signed Logistics Exchange of memorandum Agreement in 2016 and it also became the major defence partner of the Washington.

4. New Delhi's role in Afghanistan can be seen as a counter balance to the growing Chinese influence in the region as the US forces has signed a peace deal with the Taliban in March 2020. The deal will provide the significant role of China due to the Pakistan's influence over the Taliban.

India has played a significant role in Afghanistan's development since the US invasion of Afghanistan in 2001 as the new government has not been friendly towards the Pakistan due to its close links with the Taliban. India has pumped in more than US\$ 3 billion in the development of the Afghanistan in order to ouster the Pakistani influence on the Afghan political as well as social scenario. India also signed the strategic partnership with Afghanistan in 2011 and the development of the Chabhar port can be viewed in this perspective as it not only provides a base for the India to trade with Afghanistan but also provides it an access to the warm waters through Chabhar.

Although India seems to have covered the lot of areas in Afghanistan but still the Taliban insurgency is at its height and the Taliban-US talks for the future of Afghanistan in Qatar can play a significant role due to the fact that Taliban have no links with the Indian government but it is Pakistan who enjoys friendly ties with them.

\footnotetext{
*** India and US has called the Chinese aid/loan as a trap to the states in order to fulfil Chinese strategic interests in the region.

t++ US has withdrawn from the TPP in January 2017.
} 
5. The objections raised by Indo-US nexus over the development of the China -Pakistan Economic Corridor (CPEC) has been a major concern. Chinese president in 2013 has unveiled his ambitious project

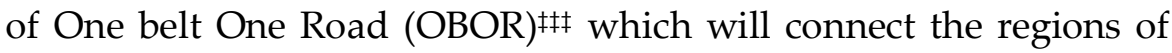
Africa, Europe and Middle East which involves 1000 infrastructure projects costing over Chinese assistance of US \$ 1 trillion (Frankopan, 2018; p-15). New Delhi has been concerned about the String of Pearls $\$ \$$ and the Chinese development of infrastructure projects in South Asia particularly the CPEC an extension of the larger project of BRI.

Beijing proposed New Delhi to join the regional free trade, The Regional Comprehensive Economic Partnership, which includes South Korea, Japan, Australia, New Zealand, and ASEAN members in order to promote regional trade. (Kazmin, 2019)

New Delhi's presence at Chabhar will present a new challenge to the Gwadar as India and Iran wanted the port to compete with the Gwadar port. The Chabhar is over 100 kilometre away from the Gwadar port, and provides an alternate route to the Kabul and other Central Asian Republics to access to the warm waters.

6. Indian design to malign the Islamabad and impose sanctions through international organizations United Nations when it tried to designate Jaishe Mohammad (JeM) chief Molana Masood Azhar as terrorist (PTI, 2018). New Delhi over the years propagated against the Islamabad by calling it the safe havens for the extremists.

抽 Also known as Belt \& Road Initiative (BRI)

$\S \S \S$ String of pearl, in geo-strategic parlance, refers to the Strait of Malacca, Sri Lanka, Pakistan, the Maldives, the Strait of Hormuz and Somalia. It also includes Bangladesh and Myanmar in Chinese strategy. (Dutta, 2017). The Chinese build-up of the ports at Chittagong (Bangladesh), Hambantota (Sri Lanka), and Gwadar (Pakistan) is viewed as encirclement of the India. 
India has blamed Pakistani government of harbouring and sponsoring the Jihadi groups involved in the Kashmiri freedom fight, and has even alleged the Pakistani authorities of providing safe havens to the terrorist groups. The events such as Indian Parliament Attack in 2001, Mumbai Attacks of 2008, Uri Attacks in 2019 and all other terrorists activities in India has been blamed on the Pakistani authorities in order to convince the world that Pakistan is a sanctuary of terrorist groups.

The latest crisis between India and Pakistan occurred in the month of February 2019 when the Indian forces were attacked by the suicide bomber in which more than 40 Indian soldiers died. The occurrence led the Indian government to propagate against Pakistani government of sponsoring the terrorists without evidence.

The global war on terror has been the major reason of Indian propagation against the Pakistan as South Asia particularly the Afghanistan and Pakistan border region is difficult to monitor due to the influx of Afghan refugees. Pakistan has tried to establish the law and order in this region, and has fought the Operations Zarb-e-Azb and Rad-ul-Fasad against these extremist forces in the country and has fenced the Pak-Afghan border in order to curtail the illegal entry points of non-state actors.

\section{Conclusion}

New Delhi has emerged as a regional power since its independence due to its sheer geographical size and shares its borders with all the South Asian states with huge resources. The only state that stood against it in the region was the Pakistan and it engaged in multiple wars with it. New Delhi Act East Policy, and its strategic partnership with the Washington has created its maps as global power. New Delhi has been aspirant for the membership of the United Nations (UN) permanent seat, and Washington remains the key supporter of the New Delhi's aspirations. But the major challenge remains from the 
Islamabad which remains the major competitor to the New Delhi in the regional and global politics and its role cannot be denied in various issues such as Afghan War, Middle East and Indian Ocean and last but not least is its alliance with the Beijing.

New Delhi's aspiration of becoming the regional and global power is hindered by the Pak-China axis as they present the alternate to the regional states against the Indian hegemonic designs. Despite being an emergent nation in the region New Delhi has been unable to counter the Beijing-Islamabad axis due to the fact that both have forged close ties and has been able to counter the narrative used by New Delhi and Washington of harbouring terrorists and Chinese designs of dominating the region.

\section{References}

Basit, S. H. (2019). CPEC emboldens China and Pakistan's joint effort to manage militancy. Retrieved from https://thediplomat.com /2019/04/cpec-emboldens-china-and-pakistans-joint-effort-tomanage-militancy/

Dutta, P. K. (2017). Can China really encircle India with its String of Pearls? The great game of Asia. Retrieved from https://www.indiatoday.in /india/story/china-encircle-india-string-of-pearls-982930-2017-06-15

Frankopan, P. (2018). The New Silk Roads: The present and the future of the world. London, UK: Bloomsbury Publishing

Gupta, B. S. (1975). Waiting for India: India's role as a regional power. Journal of International Affairs, 29(2), 171-184

Hali, S. M. (2019). Indian involvement in Sri Lanka carnage. Retrieved from https://dailytimes.com.pk/388190/indian-involvement-in-sri-lankacarnage/

India-China War of 1962: How it started and what happened later. (2016, November 21). India Today. Retrieved from https://www.indiatoday.in/education-today/gk-current-affairs/ story/ india-china-war-of-1962-839077-2016-11-21 
Kazmin. A, (2019). China-India talks to focus on the New Delhi's growing trade deficit. Retrieved from https://www.ft.com/content/5ca7683aebff-11e9-a240-3b065ef5fc55

Kissinger, H. (2014). World Order: Reflection on the character of nations and the course of history. USA: Penguin Press

Lidarev, I. (2012). History's hostage: China, India and the war of 1962. Retrieved from https://thediplomat.com/2012/08/historys-hostagechina-india-and-the-war-of-1962/

Malik, M. S. (2019). Pakistan-India relations: An analytical perspective of peace efforts. Retrieved from: http://issi.org.pk/wp-content/uploads /2019/04/4-SS_Muhammad_Sajjad_Malik_No-1_2019.pdf

Mourdoukoutas, P. (2019). India is changing the game for China and Pakistan in Kashmir. Retrieved from https://www.forbes.com/sites/ panosmourdoukoutas/2019/09/12/india-is-changing-the-game-forchina-and-pakistan-in-kashmir/\#794237aa54b9

Mourdoukoutas, P. (2019). Modi won't let China turn India to another Pakistan. Retrieved from https://www.forbes.com/sites/ panosmourdoukoutas/2019/11/08/modi-wont-let-china-turn-indiato-another-pakistan/\#15a5dcc6ebfc

Riedel, B. (2017). Catastrophe on the Yalu: America's intelligence failure in Korea. Retrieved from https://www.brookings.edu/blog/orderfrom-chaos/2017/09/13/catastrophe-on-the-yalu-americasintelligence-failure-in-korea/

Small, A. (2015). The China-Pakistan Axis: Asia's New Geopolitics. London, UK: C. Hurst \& Co. Publishers Ltd. 